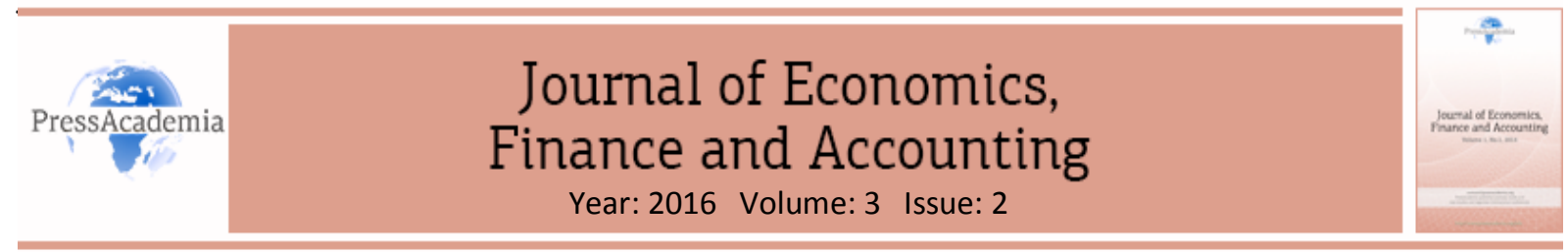

\title{
ANALYZING IMPACT OF NON-RESIDENTS' HOLDINGS OF EQUITIES ON BIST (ISTANBUL STOCK EXCHANGE) 100 INDEX $^{i}$
}

\section{DOI: 10.17261/Pressacademia.2016219779}

\author{
Ahmet Kesik ${ }^{1}$, Mehmet Canakci ${ }^{2}$, Halil Tunali ${ }^{3}$ \\ ${ }^{1}$ Yıldırım Beyazıt University. akesik@ybu.edu.tr \\ ${ }^{2}$ Ministry of Finance. mehmet canakci@yahoo.com \\ ${ }^{3}$ Istanbul University. htunali@istanbul.edu.tr
}

\begin{abstract}
Foreign portfolio investments and international capital flows have crucial effects on stock market indexes and economic performance of a country. In this article, the effects of foreign portfolio investments on fluctuations of BIST100 index were examined. In this context, data of 522 weekly time series between 07.01.2005 and 02.01.2015 were used. For stock certificates of people living abroad and the BIST100 index, time series econometrics was applied and it was tested with VAR method. In this article, in order to define the direction of causality between variables, Granger causality test, action-reaction function and variant discretisation techniques were used. "It was concluded that in BIST100 index as more foreign investors buy the stocks, the index navigates in higher levels. So foreign portfolio investments and international capital flows have impact on BIST100 index.
\end{abstract}

Keywords: Financial liberalization, foreign portfolio inflows, BIST100

JEL Classifications: E44, F21, G15

\section{INTRODUCTION}

From the beginning of 1990s, with economic and financial developments in world economy, as well as the process of rapid liberalization and internationalization of international capital markets, brought forward international movements of capital, in addition to the movements of goods and services. Process of removing controls and limitations over national financial markets, which began in USA and UK after 1970s, was accelerated with stabilization and structural harmonization programs carried out in many developing countries. The distinctive sign of this liberalization process is considered as the increase in international private capital flows. Besides that, while the largest share in international capital markets was commercial bank loans in 1970s, it was portfolio investments towards stocks and bonds in 1990's (Basoglu 2000).

Accordingly stock exchange markets are important components of global financial system. Increasing financial liberalization, international integration and capital inflowamong economies have further emphasized the importance of the relationship between stock exchange in the economic system.

As for Turkish economy, with the adoption of export-based development model in early 1980, liberalization of the economy also necessitated financial liberalization. (Boratav 2004). Semi-free exchange system, which began in 1984, remained effective till 1989. Full financial liberalization in 1989 is considered as one of the most

\footnotetext{
This article is expanded version of the summary paper presented at the 18th Finance Symposium (TURKEY)
} 
important steps towards liberalization of exchange rate regime. This decision provided the consolidation of Turkish capital market with the global financial markets, by creating the basis of the financial sector. (Turgut 2006). With such decision Turkey has become one of the most financially liberal countries in the world (Arin 2011). At the end of this liberalization process, International Monetary Fund (IMF) acknowledged Turkish Lira as a convertible currency by its own criteria (Boratav 2004).

The beginning of economic liberalization process in 1980 in Turkey, paved the way for in flow of international capital, as well as domestic savings, in order to make the investments needed for the growth and development of the country (Acikgoz 2006). High interest rate policy, for attracting international capital to the country was the most important part of the financial liberalization process. In the past few years, increase in revenue of growing nations has gradually increased. At the same time a number of contributing factors can be realised as engines to this cause, and all several pull factors have also played a significant role this. Most growing economies have improved their macroeconomic stability by implementing favourable monetary and fiscal policies. The increase of income in growing economies has evolved economic strenght at the same time produced incunberences for policy makers of these nations. The economic and financial regression or slump of 2001, Turkey has used this opportunity as a springboard to develop its economic policies by putting up strong monetary and fiscal policies which have generated large income/capital inflows. (Yorukoglu and Cufadar 2008)

Therefore, successful fiscal discipline and financial stability process of Turkish economy that was witnessed in recent years, also brought along an increase in foreign portfolio investments over years. International capital flows became a subject of researches on the effects over the macroeconomic balances of developing countries like Turkey, as a result of the economic problems occurred in such countries following liberalization processes (Acikgoz 2006).

Today in Turkish capital markets, persons residing abroad have bonds worth of 61.134 million USD and government debt securities worth of 51.051 million USD. One year ago (10th May 2013) these figures were 80.831 million USD and 71.732 million USD, respectively.

In this paper, the relationship between the profit of BIST (Istanbul Stock Exchange) 100 index and the foreign portfolio investments in Turkey is analyzed between January 2005-May 2015. As the Central Bank of the Republic of Turkey began to collect and publish data of stocks and bonds that owned by people living abroad in 2005, the year of 2005 was set as the starting date for data in this study. In Part 2, theoretical framework was given. In Part 3, a general description of international capital flows and portfolio investments was made and vector auto regression model was explained. In Part 4, implementation of the subject was summarized with its phases. In Part 5 results and explanations for future researches were given.

\section{LITERATURE REVIEW}

\subsection{Empirical Evidence}

Theoretical basics of the financial liberalization are the studies of McKinnon ${ }^{\mathrm{ii}}$ and Shaw ${ }^{\mathrm{iii}}$. The theory, which is based on the assumption that financial liberalization reshapes the distribution of savings throughout the world and equalizes the interest rates of countries, claims that removing financial stress and providing financial deepening creates an effective resource distribution and speed up economic development (Williamson 2002). Many criticisms have been made against financial liberalization theory by different schools of economics. NeoKeynesian approach contradictive argues that financial liberalization policies negatively affect savings, investments and economic growth. According to this approach, availability of high rates of real interest and borrowable funds in the markets places banking sector in a riskier position and the financial liberalization policies that are being implemented causes financial crises inflicted by the risky structure of banking sector (Hepsag 2009).

Jun made a research on South Korean capital markets in 1995, He concluded that foreign investment worth one billion USD caused an average increase of $24 \%$ on stock prices in Korean Stock Exchange. Bekaert and Harvey (1998) have examined the portfolio investments flowing into 17 developing countries from USA. In the study, it was concluded that the increase in stock and security flows into developing countries was resulted an increase in economic growth per capital in such developing countries. Levine and Zervos (1998). Rogoff (1999), studied 
the effect of international portfolio investments over growth and the development of markets, Both concluded that foreign capital movements positively contributes to the development of markets and therefore influential on long-term development of economies. McLean and Shrestha (2002), in their study on 40 developing countries from 1976 to 1995, confirmed a positive and significant relation between portfolio investments and economic growth. In the study, it was concluded that portfolio investments positively affects economic growth, while capital inflows as commercial loans negatively affected economic growth.

Yeldan et al. (2002), analyzed determinants of short-term foreign capital movements after Turkey liberalized capital accounts. In their study, they have concluded that capital movements in 1992-2002 period had a positive correlation with the real increase in national currency. Pazarlioglu and Gulay (2007), suggests foreign capital has many benefits including new sales, new business opportunities, employment and income for the host countries. Poshakwale and Thapa (2007), researched the effect of portfolio investments on Indian stock markets, using VAR method. In the study, they concluded that Indian stock markets significantly react to portfolio investments. Keskin (2008), has analyzed the effects of portfolio investments and short-term capital movements towards Turkey over exchange rates, interest rates, foreign exchange reserves and current account balance. In the results of the analysis made using data of 1992-2007 period, portfolio investments and shortterm capital movements towards Turkey were indicated as negatively affecting current account balances by causing a rise in the real value of national currency in long term. Moreover, it was concluded that portfolio investments cause a decrease of interest rates and an increase in foreign exchange reserves in long term.

Somuncu et al. (2010), examined the role of international investors in the financial crisis of 2001, by analyzing the effects of the two basic strategies of international investors over IMKB. These two strategies are positive feedback trading and herding behavior. Findings in their study indicate that while foreign investors were involved in negative feedback trading, local investors were involved in positive feedback trading. Vergil and Karaca (2010), in their study on 25 developing countries in 1980-2005 period, have concluded that foreign direct investments and portfolio investments positively affect economic growth of these countries, while shortterm capital movements negatively affect them. Elmas (2012), has examined the effects of foreign portfolio investors on BIST in 2010 in an index-based study. It was determined that foreign investment movements generally were not the initiators of rise or falls of BIST100. Naik and Padhi (2015), examined the relationship between institutional investment flow and stock returns using daily data over the period of January 1, 2002 to July 31,2012 , in their study Indian stock market and Investors. The analysis was conducted using two and three factors vector autoregression (VAR) frameworks have found a feedback relationship between the institutional investment flow and stock market returns. Overall, it was found that the institutional investment collectively impacted the stock market returns.

\subsection{Theoretical Framework}

International capital flows showed great increase beginning in 1990s. This increase occurred depending on two important developments that allow international portfolio diversification. Firstly, developing countries significantly increased their integration into international markets by liberalizing their financial markets, exchange regimes and stock accounts and opening them to foreign investors. They also increased investment opportunities with privatizing public establishments and supporting the creation of deeper and more liquid financial markets (Moreno 2000). Secondly, improvements in information and communication technologies facilitated evaluation and monitoring of investments throughout the world and enabled the funds in developed countries to flow in international markets. Especially the developments in communication technologies made it easier for foreign funds to make investments abroad, by providing means for getting informed about investments and supporting the occurrence of more effective financial instruments (Moreno 2000).

Integration process of national and international financial markets which gained momentum in 1990s, also created the phenomenon of "financial crisis". It can be suggested that two important developments led the economic crises in the world. One of them is the "bubble economy" which generally affects developed countries, and the other one is international capital flows which play role in the crises in developing countries. There are two primary effects of international capital flows that lead to crises in developing countries: One of them is speculative attacks on the country and other is the behavioral changes of economic actors in the 
country as a result of the abundance of liquidity. Consequently, liberalization of capital flows is thought to be an element capable of leading to crisis by itself (Ozmen 2011).

There are several factors attracting capital flows into a country or preventing them out of the country. Many researches were focused on the importance of "push" and "pull" factors over capital flows among countries, especially developing countries. Push factors are exogenous for any country and encourage investments for capital outflows. Economic stagnation in developed countries, low interest rates and political tensions are some of push factors leading existing capital towards developing countries (Pazarlioglu and Gulay 2007).

Along with push and pull factors, the very concept of financial integration is also one of the primary reasons of capital flows. Increasing capital flows is a result of financial integration, which is strengthened by the revoking of obstacles against capital flows, as well as push and pull factors. In recent years, with developed and developing countries removing obstacles arising from their foreign expansion policies, capital is able to roam in international platforms freely and this accelerates capital flows among countries (Inadim 2005).

\section{Portfolio Investments}

Portfolio investments are defined as the investments of savers in international capital markets on stocks, bonds and other capital market instruments for acquiring capital gains, interest, dividend income etc. by undertaking additional risks like political risks, country risks, exchange risks, economic risks and information risks. ${ }^{\text {iv }}$

Portfolio investments, which are defined as investments on securities, generally comprise of bonds and securities of public and private establishments, stocks and other monetary market investments. ${ }^{v}$ For this reason, there are some important differences between direct and portfolio investments. The most significant one is about the management and supervision of an abroad investment. In a case of direct investment company, investor can be influential in management and supervision. In portfolio investments, there is not a right of management or supervision over the established company; in that way the company itself provides funds from international markets. As the second important difference, while in direct investments the investor can put into use of his/her know-how on production technologies and managership along with capital, in portfolio investments foreign investor has no other contribution but the capital. ${ }^{\text {vi }}$

Agarwal has counted inflation, real exchange rate, market value and some other indicators about economic activities as major determinants of portfolio investments (Agarwal 1997).

Evans shows that describing portfolio investments as "bad" and direct investments as "good" is oversimplifying a complex issue. He claims that these two types cannot be valued as "good" or "bad" and policy makers has to create arrangements from these two types in order to increase economic growth (Evans 2002).

IMF, in its report on global financial stability in April 2014, which is sort of an analysis on portfolio flows, stated that global financial system needs more stability and therefore it is going through a tough period. Besides that, this tough transition was foreseen as from liquidity-based growth to accessing in growth-based markets, and it was stated that in order to achieve this, financial stability risks have to be decreased; in this regard monetary policies of USA has to be normalized and financial conditions and corporate debt levels to be rebalanced. Also it was mentioned that the role of local financial systems has to be reviewed for the structure of investor base, portfolio flows in rising markets and stability of asset values.

Beside the negative effects of portfolio investments on countries, there is also a commonly-held opinion among economists that these investments may provide three kinds of benefits to real sector in an economy. First of all, portfolio investments can provide a debtless foreign investment source to developing countries. Amount of capital in developing countries is generally scarce; therefore these countries need to eliminate the "savings gap" in order to succeed in their development efforts. Portfolio investments can add to domestic savings for improving the value of investment rate. Secondly, increase in foreign capital flow into a country can improve the efficiency of capital allocation in the country. In this view, portfolio investments can encourage monetary capital sources, like direct foreign investments, to flow into a country from capital-rich low-yield countries. Flow of funds to capital-poor countries has effects over these countries, such as decreasing costs of capital, increasing investments and goods produced in a specific time and with a specific amount of production factors. 
Thirdly and most importantly, the most prominent advantage of portfolio investments to investee country is the increase of prices in domestic stock market (Pazarlioglu and Gulay 2007).

\section{Relationship between Portfolio Investments and Stock Yields}

In order to describe the effects of foreign portfolio investments over stock yields, several approaches were hypothesized. (Dogukanli and Cetenak 2008)

Hypothesis of Base Broadening

According to hypothesis of base broadening, an increase in investor base as a result of the flow foreign portfolio investors may cause sharing the risk, so that a decrease in risk premia may occur. With decreasing risk premia, a permanent price rise may occur in stocks. (Clark and Berko 1996)

\section{Expected/Unexpected Flow Hypothesis}

According to expected/unexpected flow hypothesis, as a result of permanence of foreign investments, reactions given to these investments in markets will be reflected to prices in advance. Local investors, who presume the amount of coming foreign investment, will make their price settings accordingly and therefore when the flow realized with the expected amount, they will not make a significant effect. However, unforeseen foreign capital flows will encounter a price reaction in the market. (Clark and Berko 1996)

\section{Feedback Hypothesis}

Investors who define their market behaviors according to price movements before are called feedback investors. So a feedback investor would buy stocks when markets rise and sell when markets fall. Volatility of portfolio investments and its rapid flow among countries is attributed to the investment strategies of this kind of foreign feedback investors. Negative feedback investors sell their stocks in their portfolio when markets rise and buy while markets fall. This strategy generally results from movements in exchange rates. In rising times, the negative feedback investor sells his/her stocks taking advantage of the high value of local currency ad he/she returns to the markets and make cheap purchases when the local currency lose value. (Dogukanli and Cetenak 2008)

\section{Price Pressure Hypothesis}

According to price pressure hypothesis, large volumes of foreign portfolio investments create pressure over local developing markets because of the shallowness of the markets and the scarcity of liquidity in these markets, therefore price pressure occurs and prices rise artificially. As a result of the market not being liquid enough, inflow of foreign capital causes an increased liquidity and so an excessive rise in prices, the prices return to normal levels with a delay. In other words, in regard to price pressure hypothesis of Warther in 1995, price rises following fund inflows is temporary. (Clark and Berko 1996)

\section{Vector Auto-Regression Model}

A vector auto-regression (VAR) model that handles two time sequence variables like $Y_{t}$ and $X_{t}$, consists of two equations. In one of these equations, dependent variable is $Y_{t}$ and in the other one it is $X_{t}$. In both equations, explanatory variables are the delayed values of the two variables. VAR model, in this way, is a model in which, there is $k$ pieces of time sequence variables and $k$ pieces of equations, being having one for every two variables; also in which all delayed values of all values are explanatory variables in all equations. Coefficients of VAR model are calculated by estimating every equation with OLS (Stock and Watson 2007).

Complexity and versatility of interactions among economic relations necessitate the usage of simultaneous equation systems. Besides, difficulties of determining dependent and independent variables, which are naturally occurring as a result of the mutual interactions among economic parameters, also significantly affect the coherency of analysis. For this reason, some limitations have to be done on the structural model in simultaneous equation systems, in order to overcoming the determination problem (Adrian and Darnell 1990). With VAR model, which is designed to solve this complex situation in simultaneous equation systems, this problem is eliminated. VAR models are being used frequently in time sequence series, as they can show dynamic relations without making any limitations to structural model (Keating 1990). 
VAR model differentiates from simultaneous equation systems with its lack of necessitation for any distinction between internal and external variables, by relying on any economic theory. Also, as there are delayed values of dependent variables in VAR models, it is possible to make strong predictions for future (Kumar, Leona and Gaskins 1995).

Another area of utilization of VAR models is to examine the causality between time sequence variables. First usage in this respect was in 1980 by Sims (Sims 1980). Usage of VAR models for causal inferences is known as structural VAR model (Stock and Watson 2007). For analyzing the relations between variables within VAR model, following steps are used in order (Mucuk and Alptekin 2008).

1. Reviewing the stationarity of all variables to be included in the model, using unit root tests,

2. Determining optimal time lag length, using information criteria,

3. Determining long-term and short-term relations between variables, using cointegration and Granger causality tests,

4. Estimating VAR model and making structural tests,

5. Evaluating the correlation, using impulse-response functions and variance analysis.

\section{DATA AND METHODOLOGY}

The study analyzes the effects of foreign portfolio investments on fluctuations of BIST100 index were examined. The data starting date is since the year 2005 in the EVDS of CBRT (Electronic Date Delivery System of Central Bank of Republic of Turkey) system. Therefore Weekly data were used between 7 January 2005 and 2 January 2015. Accordingly, number of observations for each variable occurred as 522. Eviews 6 software was used in the study. Abbreviations about and sources of these data is shown below in Table 1.

Table 1: Variables Emplyed in the Study

\begin{tabular}{l|l|c} 
Abbreviations & Explanation & Source \\
\hline XU100TL & Istanbul Stock Exchange 100 Index (TL) & Bloomberg \\
\hline XU100USD & Istanbul Stock Exchange 100 Index (USD) & Bloomberg \\
\hline LXU100USD & $\begin{array}{l}\text { Corrected Logarithmic Istanbul Stock } \\
\text { Exchange 100 Index (USD) }\end{array}$ & \\
\hline DLXU100USD & $\begin{array}{l}\text { (First Difference) Corrected Logarithmic } \\
\text { Istanbul Stock Exchange 100 Index (USD) }\end{array}$ \\
\hline TPPYUK & Non-Resıdents' Holdıngs Of Equitıes (USD) & CBRT \\
\hline LXU100USD & $\begin{array}{l}\text { Corrected Logarithmic Non-Resıdents' } \\
\text { Holdıngs Of Equitıes (USD) }\end{array}$ & \\
\hline DLXU100USD & $\begin{array}{l}\text { (First Difference) Corrected Logarithmic Non- } \\
\text { Resıdents' Holdıngs Of Equitıes (USD) }\end{array}$ & \\
\hline
\end{tabular}

Daily closing values of Borsa Istanbul 100 Index were converted to US Dollar with the exchange rates released by Bloomberg. As there is no data of XU100TL and TPPYUK for 13 January 2006, average of the values of the next and previous days. TPPYUK is being released in terms of million US Dollars by CBRT. Information about data is shown below.

\section{Methodology}

Method of time-series econometrics was used in this study. In this context, unit root tests were done for stationarity of series used in the model. In the context of VAR, in order to define the direction of causality between variables used in the model, techniques of Granger causality test, action-reaction function and variance decomposition were used. 


\section{The Model}

VAR model consists of two variables. Stocks belonging to non-residents and Borsa Istanbul100 Index are in the model. The first variable was taken from CBRT (Central Bank of the Republic of Turkey) in terms of US Dollars. The latter is the converted value of BIST 100 Index, according to exchange rate released by Bloomberg.

As the data of the first variable is released weekly by CBRT, also the weekly values of the second variable were used.

TPPYUK $_{t}=a_{0}+\sum a_{1 i}$ TPPYUK $_{t-i}+\sum a_{2 i}$ XU100USD $_{t-j}+\mu_{t}$

$\mathrm{XU100USD}_{t}=b_{0}+\Sigma b_{1 i}$ TPPYUK $_{t-i}+\Sigma b_{2 i} \mathrm{XU100USD}_{t-j}+v_{t}$

The symbols here mean;

TPPYUK $_{t}=$ Stocks belonging to non-residents in the period of $t$ (in USD)

$\mathrm{XU100USD}_{t}=$ Borsa Istanbul 100 Index in the period of $\mathrm{t}$ (in USD)

$\mu_{t} v_{t}=$ Stochastic error terms

\section{FINDINGS AND DISCUSSIONS}

TPPYUK average is 45 billion USD and the standard deviation for it is 15 billion USD. For the same period, XU100USD average is 32,628 USD and its standard deviation is 8,451 USD. In the Figure 1 below, data of XU100TL was drawn. As a result of global economic crisis at the end of 2008 and in the beginning of 2009, financial problems arose and investment positions were negatively affected; therefore BIST100 index was also significantly affected, as it can be seen in Figure 1.

Figure 1: Data of XU100TL Drawn

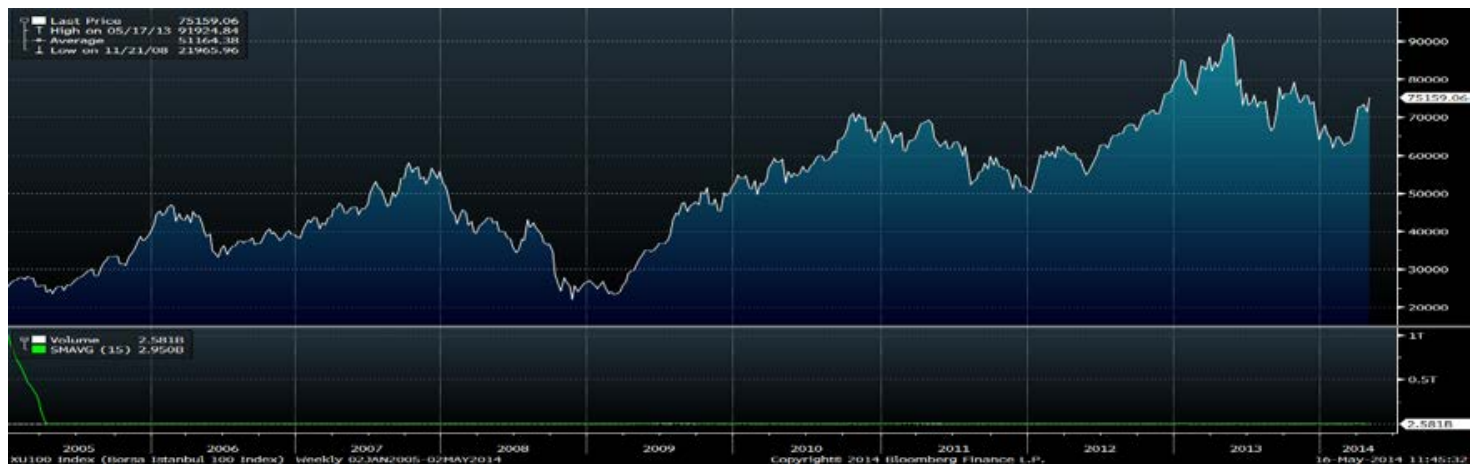

Source: Bloomberg terminal

Table 2: Summary Statistics of the Variables Used in Study

$\begin{array}{lccc} & \text { TPPYUK } & \text { XU100TL } & \text { XU100USD } \\ \text { Mean } & 44955.80 & 51147.99 & 32628.14 \\ \text { Median } & 45957.00 & 51380.65 & 33352.51 \\ \text { Maximum } & 82288.00 & 91924.84 & 50665.10 \\ \text { Minimum } & 15098.00 & 21965.96 & 12970.63 \\ \text { Std. Dev. } & 15378.28 & 16224.38 & 8451.052 \\ \text { Skewness } & -0.052232 & 0.158087 & -0.184902 \\ \text { Kurtosis } & 2.342034 & 2.190360 & 2.504724 \\ \text { Jarque-Bera } & 9.006083 & 15.33000 & 7.752515 \\ \text { Probability } & 0.011075 & 0.000469 & 0.020728 \\ \text { Observations } & 522 & 522 & 522\end{array}$


XU100USD data in the following Figure 2 TPPYUK scratching was observed that once the stock index and the relationship continued to growing up

\section{Figure 2: Data of TPPYUK and XU100USD Drawn}

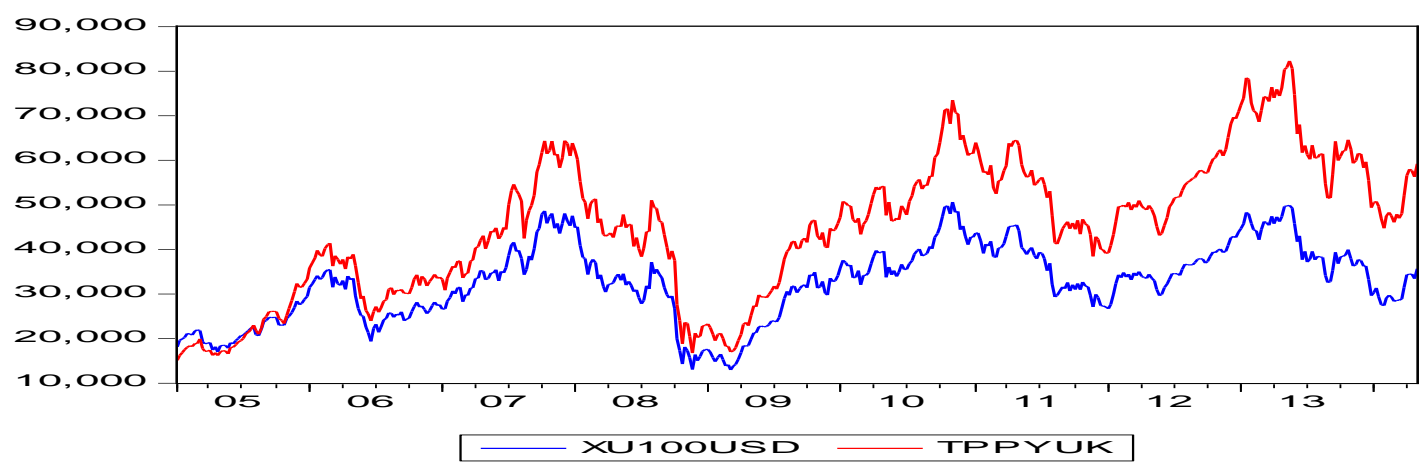

Correlation matrix of variables was given below in Table 3. Accordingly, correlation coefficient between TPPYUK and XU100USD is 0.95 . This shows a positively strong relation between these two variables.

Table 3: Correlation Matrix

\begin{tabular}{|c|c|c|}
\hline & XU100USD & TPPYUK \\
\hline XU100USD & 1 & 0.954150 \\
\hline TPPYUK & 0.954150 & 1 \\
\hline
\end{tabular}

\section{Stationarity}

In case of studying with non-stationary time-series, problem of spurious regression may arise. Therefore, in studies that use time-series, it is needed to be begun with analyzing the stationarity of the series. Stationarity of time-series means the variance and mean to be constant in time and co-variance of variables in two delayed time periods to be depended on the delay, instead of time.

In order to analyze stationarity of time-series, many methods are being used, such as simplified Dickey-Fuller (ADF) unit root test, Phillips-Perron unit root test and Kwiathowski-Phlips-Schmidt-Shin unit root test. In this study, ADF unit root test was used for analyzing stationarity.

Table 4: Unit Root Test Results

\begin{tabular}{llccccc} 
& TPYUK & LTPPYUK & DLTPPYUK & XU100USD & \multicolumn{2}{c}{ LXU100USD DLXU100USD } \\
\hline t-Statistic & -2.057660 & -2.404471 & -20.79760 & -2.420212 & -2.397456 & -22.09035 \\
\hline Prob. & 0.2623 & 0.1410 & 0.0000 & 0.1367 & 0.1430 & 0.0000
\end{tabular}

First-Difference-Deduced Logarithmically-Corrected Borsa Istanbul 100 Index (DLXU100USD) and FirstDifference-Deduced Logarithmically-Corrected Stocks Belonging to Non-Residents (DLTPPYUK) fulfilled the condition of stationarity and were drawn in Figure 3. 
Figure 3: Series of Stationarity DLXU100USD and DLTPPYUK Drawn

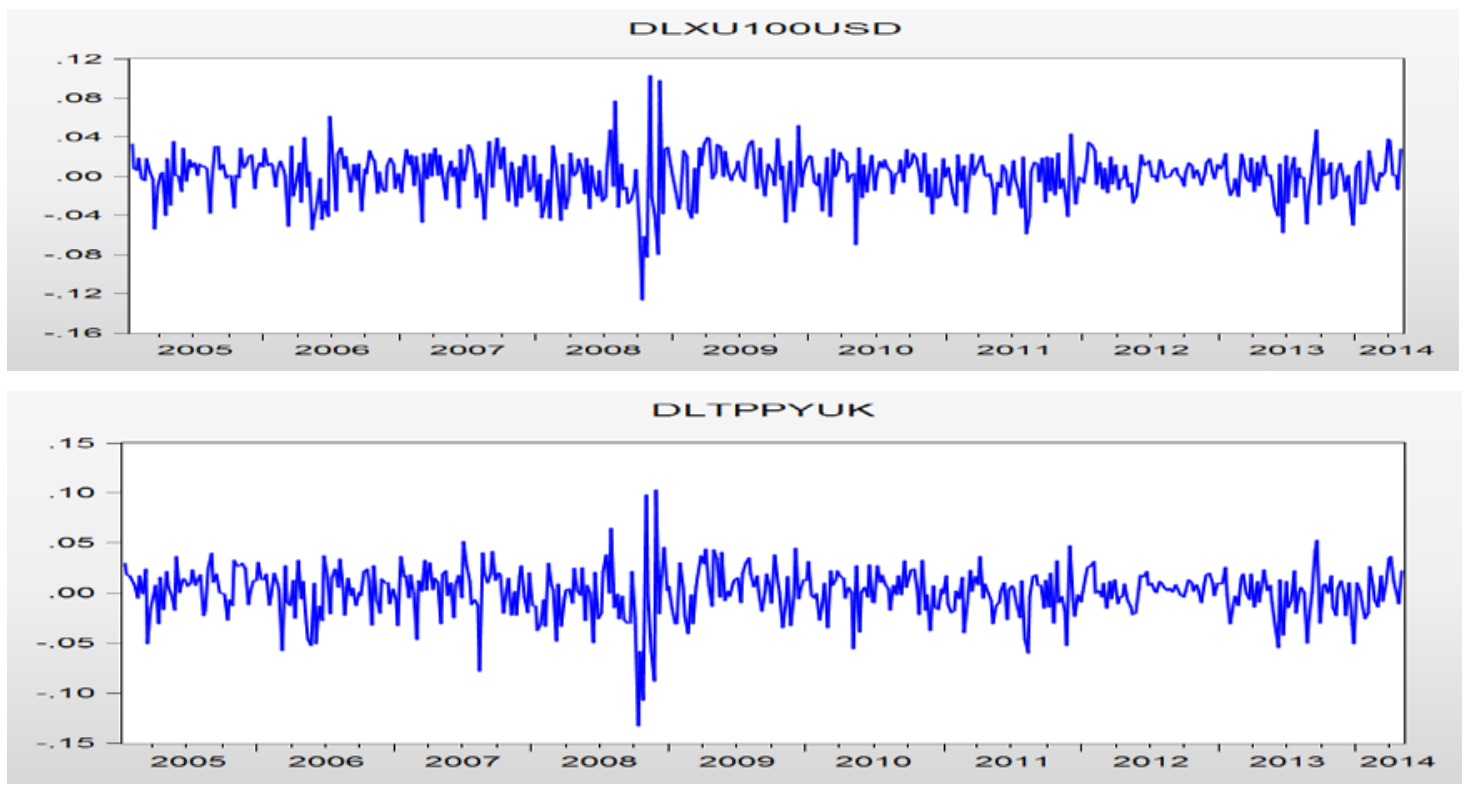

\section{Number of Delay}

In VAR analysis, number of delays of series in the model is needed to be determined. Number of delay in the model was determined as Hannan-Quinn and Schwarz criteria. Accordingly, as it is seen in Table 5, number of delay is 2 .

\section{Table 5: VAR Lag Order Selection Criteria}

\begin{tabular}{ccccccc}
\hline \hline Lag & LogL & LR & FPE & AIC & SC & HQ \\
\hline \hline 0 & 2672.199 & NA & $4.39 \mathrm{e}-08$ & -11.26666 & -11.24910 & -11.25976 \\
1 & 2751.150 & 156.9029 & $3.20 \mathrm{e}-08$ & -11.58291 & -11.53024 & -11.56219 \\
2 & 2766.329 & 30.03860 & $3.05 \mathrm{e}-08$ & -11.63008 & $-11.54229^{*}$ & $-11.59555^{*}$ \\
3 & 2771.806 & 10.79224 & $3.03 \mathrm{e}-08$ & -11.63631 & -11.51341 & -11.58798 \\
4 & 2776.954 & $10.10072^{*}$ & $3.02 \mathrm{e}-08^{*}$ & $-11.64116^{*}$ & -11.48314 & -11.57901 \\
5 & 2779.017 & 4.029967 & $3.04 \mathrm{e}-08$ & -11.63298 & -11.43985 & -11.55703 \\
6 & 2783.094 & 7.930445 & $3.04 \mathrm{e}-08$ & -11.63331 & -11.40506 & -11.54354 \\
7 & 2783.416 & 0.623060 & $3.09 \mathrm{e}-08$ & -11.61779 & -11.35442 & -11.51421 \\
8 & 2785.492 & 4.003619 & $3.11 \mathrm{e}-08$ & -11.60967 & -11.31119 & -11.49228 \\
9 & 2788.227 & 5.250103 & $3.13 \mathrm{e}-08$ & -11.60433 & -11.27073 & -11.47313 \\
10 & 2792.389 & 7.956150 & $3.13 \mathrm{e}-08$ & -11.60502 & -11.23630 & -11.46001 \\
11 & 2792.999 & 1.161005 & $3.17 \mathrm{e}-08$ & -11.59072 & -11.18688 & -11.43189 \\
12 & 2797.258 & 8.067915 & $3.17 \mathrm{e}-08$ & -11.59181 & -11.15286 & -11.41917 \\
\hline \hline
\end{tabular}

* indicates lag order selected by the criterion

LR: sequential modified LR test statistic (each test at $5 \%$ level)

FPE: Final prediction error

AIC: Akaike information criterion

SC: Schwarz information criterion

HQ: Hannan-Quinn information criterion

It can be understood from Figure 4 below, which shows that all inverse roots of AR characteristic polynomial fall into the unit circle, that the estimated VAR model is stationary according to determined number of delay. 
Figure 4: Inverse Roots of AR Characteristic Polynomial

Inverse Roots of AR Characteristic Polynomial

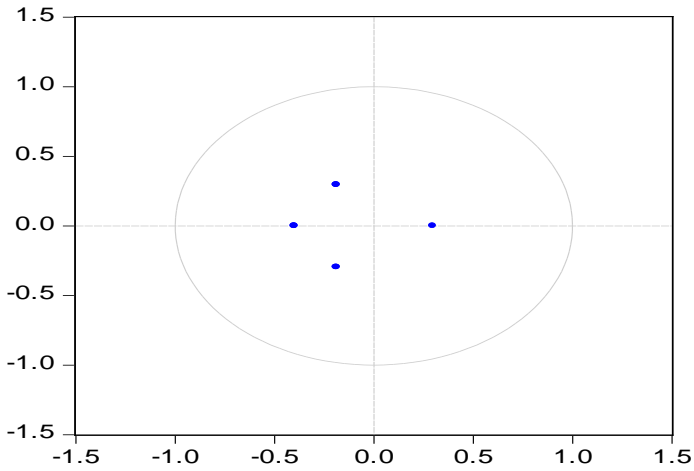

\section{Causality}

In order to determine the direction of causality between variables, VAR Granger causality/Block Externality Wald test was applied. As it can be seen in Table 6 below, there is a two-way causality between stocks belonging to non-residents and Borsa Istanbul 100 Index.

Table 6: VAR Granger Causality/Block Exogeneity Wald Tests

\begin{tabular}{cccc}
\hline \hline \multicolumn{2}{l}{ Dependent variable: DLXU100USD } & & \\
\hline \hline Excluded & Chi-sq & df & Prob. \\
\hline \hline DLTPPYUK & 6.961964 & 2 & 0.0308 \\
\hline \hline All & 6.961964 & 2 & 0.0308 \\
\hline \hline Dependent variable: DLTPPYUK & & \\
\hline \hline Excluded & Chi-sq & df & Prob. \\
\hline \hline DLXU100USD & 44.39983 & 2 & 0.0000 \\
\hline \hline All & 44.39983 & 2 & 0.0000 \\
\hline \hline
\end{tabular}

\section{Action-Reaction Analysis}

Action-reaction function is used for analyzing the direction and level of reaction that shown against the shocks in error terms of series in VAR model. Accordingly, the reaction of other series can be observed when one unit of shock is applied to one of the series. So, action-reaction functions reflect the effects on present and future values of internal variables, in case of a shock of one standard deviation of one of the random error terms. In Figure 5 below, results of action-reaction function are shown (Vertical axis is action and horizontal axis is reaction).

Accordingly, one unit of shock in stocks belonging to non-residents has a negative effect on Borsa Istanbul 100 Index, and only in the second period.

On the other hand, one unit of shock in Borsa Istanbul 100 Index does not have any positive effects on stocks belonging to non-residents in the first three periods.

Figure 5: Impact - Response Functions 
Response to Cholesky One S.D. Innovations

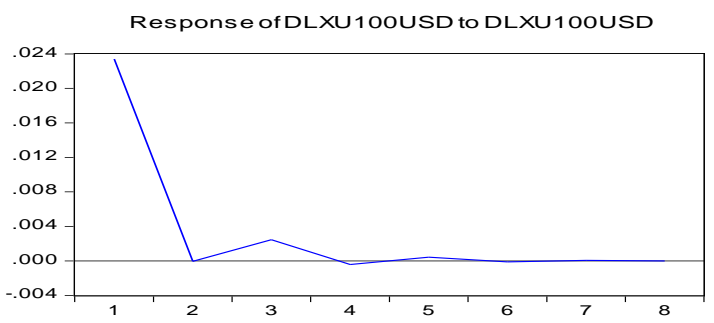

Response of DLXU1OOUSD to DLTPPYUK
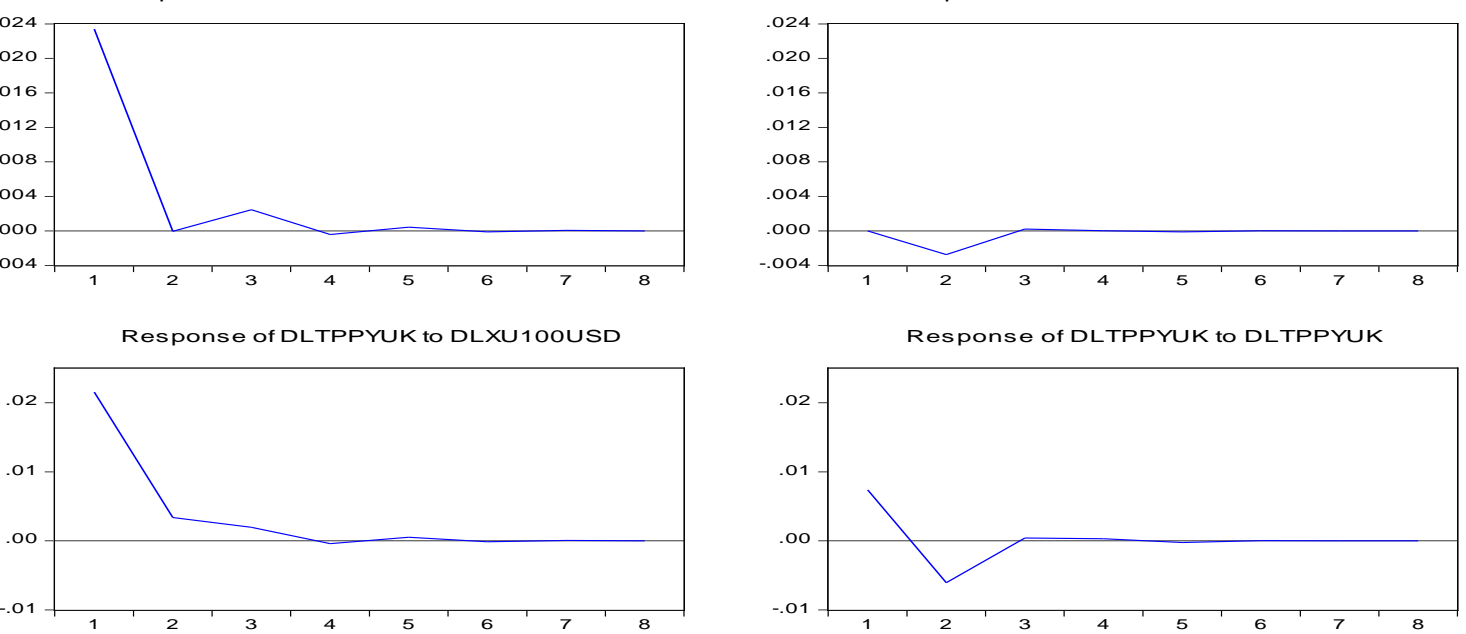

Response of DLTPPYUK to DLTPPYUK

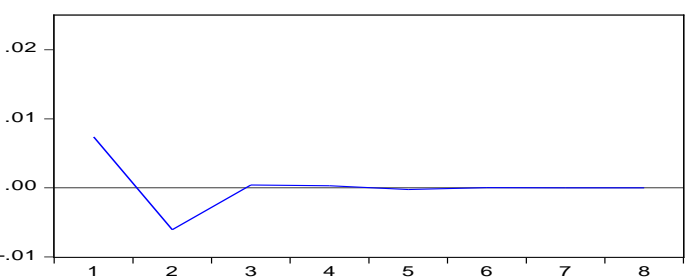

\section{Variance Decomposition}

Variance decomposition is used in determining the direct and indirect effect between variables. It reflects in percentages the sources of shocks in variables themselves and in one of other variables. In other words, it shows how much percent of change in a variable is originated from itself and from other variables. If all of the changes in a variable originate from the shock inside, this means that variable moves externally; and if they originate from other variables, this means that variable is internal. Results of variance decomposition for 12 periods were shown below.

\section{Table 7: Variance Decomposition Results}

\begin{tabular}{|c|c|c|c|c|}
\hline \multicolumn{5}{|c|}{ Variance Decomposition of DLXU100USD: } \\
\hline Period & & S.E. & DLXU100USD & DLTPPYUK \\
\hline & 1 & 0.023411 & 100.0000 & 0.000000 \\
\hline & 2 & 0.023573 & 98.63063 & 1.369368 \\
\hline & 3 & 0.023701 & 98.63681 & 1.363194 \\
\hline & 4 & 0.023705 & 98.63720 & 1.362798 \\
\hline & 5 & 0.023709 & 98.63575 & 1.364249 \\
\hline & 6 & 0.023709 & 98.63574 & 1.364264 \\
\hline & 7 & 0.023709 & 98.63574 & 1.364255 \\
\hline & 8 & 0.023709 & 98.63574 & 1.364258 \\
\hline \multicolumn{5}{|c|}{ Variance Decomposition of DLTPPYUK: } \\
\hline \multirow[t]{9}{*}{ Period } & & S.E. & DLXU100USD & DLTPPYUK \\
\hline & 1 & 0.022786 & 89.48062 & 10.51938 \\
\hline & 2 & 0.023821 & 83.88764 & 16.11236 \\
\hline & 3 & 0.023906 & 83.97416 & 16.02584 \\
\hline & 4 & 0.023911 & 83.96478 & 16.03522 \\
\hline & 5 & 0.023919 & 83.96343 & 16.03657 \\
\hline & 6 & 0.023919 & 83.96372 & 16.03628 \\
\hline & 7 & 0.023919 & 83.96378 & 16.03622 \\
\hline & 8 & 0.023919 & 83.96377 & 16.03623 \\
\hline
\end{tabular}

Cholesky Ordering: DLXU100USD DLTPPYUK 
According to the results of variance decomposition analysis of stocks belonging to non-residents, this variable is affected from itself in 10\% and from Borsa Istanbul 100 Index in $90 \%$ in short term. In long term, a change in stocks belonging to non-residents originates from itself in $16 \%$ and from Borsa Istanbul 100 Index in $84 \%$.

On the other hand, according to variance decomposition analysis of Borsa Istanbul 100 Index, this variable is affected from itself in $100 \%$ in short term. In long term, a change in Borsa Istanbul 100 Index originates from itself in $98,6 \%$ and from IMKB100 Index in 1,4\%.

\section{CONCLUSION}

In January 2005, the total value of stocks belonging ton on-residents was 15.098 million USD. In January 2015, this amount increased to 61.818 million USD. In the same period, Borsa Istanbul 100 Index rose from 18.122 to 36.520 , in USD terms. In other words, Borsa Istanbul Index in USD terms has increased by $101.5 \%$, while values of stocks belonging to non-residents have increased by $309.4 \%$. In this study, relation between stocks belonging to non-residents and Borsa Istanbul 100 Index was analyzed with VAR method, in this regard. As monthly series were used in previous studies, this study is the first research analyzing the relation in weekly series.

In the study, Borsa Istanbul 100 Index and USD exchange rates released by Bloomberg and weekly data about stocks belonging to non-residents released by CBRT were used. According to results of VAR Granger causality/Block Externality Wald test, there is a two-way causality relation between stocks belonging to nonresidents and Borsa Istanbul 100 Index.

In VAR analysis, according to results of action-reaction functions, reaction of Borsa Istanbul 100 Index towards the shocks originating from stocks belonging non-residents was negative in second period. Reaction of stocks belonging to non-residents towards shocks originating from Borsa Istanbul 100 Index was observed to be positive in three periods and to progress in a downward direction. In VAR analysis, according to results of variance decomposition, in the variance changes in Borsa Istanbul 100 Index, stocks belonging to non-residents have a share of $1,4 \%$ and $98,6 \%$ of them originate from itself. In the variance changes in stocks belonging to non-residents, Borsa Istanbul 100 Index has a share of $84 \%$ and $16 \%$ of them originate from itself.

Concludingly, it could be pointed out that, foreign investors observe the movements in Index and they increase their purchases when the Index is high and so they contribute to the current rise of the Index; and they negatively contribute to the Index by decreasing their purchases when the Index is low. Therefore, correlation between variables was clearly and significantly observed.

\section{ENDNOTES}

\footnotetext{
${ }^{\mathrm{i}}$ These data were obtained from Electronic Data Distribution System of the Central Bank of the Republic of Turkey.

ii McKinnon,R.,Money and Capital in a Developing Country, Washigton,Brookings,1973

iii Shaw,E.S.,Financial Deepening in Economic Development,New York, Oxford University Press,1973

iv This definition was quoted from the following study: BIST Research Directorate, "Portfolio Investments in International Capital Movements and Turkey", BIST Journal, November 1994

v Quoted from: Central Bank of Republic of Turkey, "Balance of Payments Methodology and Turkey Practice."

vi Quoted from: Central Bank of Republic of Turkey, "Balance of Payments Methodology and Turkey Practice."
} 


\section{REFERENCES}

Acikgoz, E. 2006. “International Capital Flows Interest Relations: The Case of Turkey.” Karaelmas University Master's Thesis, pp.2-6.

Adabag, C. M., and Ornelas, J. R. 2004. "Behavior and Effects of Foreign Portfolio Investors on Istanbul Stock Exchange." http://papers.ssrn.com/sol3/papers.cfm?abstract_id=656442. pp.13-14

Adrian, C., and Darnell, A. 1990. “Dictionary of Econometrics.” Edward Elgar Publications, pp.330-332, England.

Agarwal, R. 1997. "Foreign Portfolio Investment in some Developing Countries:A Study of Determinants and Macroeconomic Impact." Indian Economic Review, pp.217-220.

Ahmed,F.; Arezki,R.; Funke,N. 2005. “The Composition of Capital Flows: Is South Africa Different?”, IMF Working Paper.

Akar, C. 2008. "Stocks Prices Causality Between Foreign Trade Volume: Toda-Yamamato Perspective." Journal of Accounting and Finance , pp.185-191.

Albayrak,A.S.; Ozturk,N.; and Tuyluoglu,S. 2012. "The movement of capital and macroeconomic variables examined the impact of the IMKB-100 index." Journal of Economic and Social Research, pp.15-17.

Arin, T. 2011. "Accumulation of the real break from each other by the Financial Globalization and Financial Accumulation in Turkey." A. H. Kose, F. Senses, \& E. Yeldan, Essays on Economics I-Global Order: Accumulation State and Classes, pp. 571-575,Ankara,Iletisim Publisher.

Baklaci, H. 2007. "Do Foreign Investors Chase or Impact Returns in Turkey? ." International Conference on Globalization and Its Discontents. Cortland.

Barisik, S., and Acıkgoz, E. 2007. “International Capital Flows Interest Relations in Turkey.” 1992-2005 Tisk Publication 2 , no.3:198-219

Basoglu, U. 2000. "Financial Liberalization and International Portfolio Investment." Balikesir University Journal of the Institute of Social Sciences, pp.89-95.

Bekaert, G., and Harvey, C. R. 1998. "Capital Flows and The Behavior of Emerging Market Equity Returns." NBER Working Series.

Boratav, K. 2004. “Economic History of Turkey (1908-2002).” pp. 107-117, Ankara: Imge Publisher.

Boyer, B., and Zheng, L. 2009. “Investor Flows and Stock Market Returns.” Journal of Empirical Finance, no. 16, pp.87-100.

Clark, J., and Berko, E. 1996. “Foreign Investment Fluctitions and Emerging Market Stock Returns: The Case of Mexico." New York: Federal Reserve Bank of New York, pp. 2-11.

Dogukanli, H., and Cetenak, E. 2008. "Foreign Portfolio Investment with The Relationship Between Stock Returns: IMKB Test." Cukurova University Journal of Faculty of Economics, pp.40-45

Elmas B. 2012. "Istanbul Stock Exchange Effects of Foreign Portfolio Investment:A Study Based on the Istanbul Stock Exchange Index." Journal of IMKB , Volume 12, No 47,pp.1-18.

Evans, K. 2002. “Foreign Portfolio And Direct Investment Complementarity,Differences and Integration." Global Forum On International Investment. Shanghai.

Gozgur, G., and Erzurumlu, Y. 2010. "Causality Relations Between Foreign Direct Investment And Portfolio Investment Volatility." Middle Eastern Finance and Economics,pp.172-178

Hepsag, A. 2009. "Testing the Validity of Financial Liberalization McKinnon Policy Framework of Complementarity Hypothesis: The Case of Turkey." BDDK Banking and Financial Markets,pp.67-68.

Inadim, S. 2005. "Short-Term Capital Movements and Real Exchange Rate Interaction: The Case of Turkey." CBRT ExpertThesis,pp.22-25.

Jun, K. W. 1995. "Effects of capital market liberalization in Korea. In The U.S.-Korea economic partnership.", Avebury Press.

Keating, J. 1990. “Identifying VAR Models Under Rational Expectations.” Journal of Monetary Economics, pp.453-476.

Keskin, N. 2008. "Macroeconomic Effects of Financial Liberalization Process of Capital Movements in Turkey.", Journal of Finance Political \& Economic, Volume 45, No 526,pp.17-38

Kumar, V.; Leone,Robert P.; and Gaskins,John N. 1995. “Aggregate and Disaggregate Sector Forecasting Using Consumer Confidence Measures." International Journal of Forecasting Elsevier,pp.361-377

Levine, R. and Zervos,S. 1998. "Stok Market Development And Long Run Growth.” World Bank Economic Review 10.

McLean, B. and Shrestha, S. 2002. "International Financial Liberalization and Economic Growth." Reserve Bank of Australia, Research Discussion Papers.

Moreno, R. 2000. "What Explains Capital Flows." FRBSF Economic Letter. 
Mucuk,M.,Alptekin,V. 2008. "Taxes and Economic Growth Relationship in Turkey: VAR Analysis (1975 - 2006)." Journal of Maliye No 155, pp.159-174

Okuyan, H., and Erbaykal, E. 2011. "Foreign operations and stock returns in relation to the IMKB." Journal of .Dogus University 12,no. 2: 256-264

Ozmen, C. 2011. "Effects of the Financial Crisis in the financial market liberalization and Situation in Turkey." Ankara University Institute of Social Sciences, Master Thesis.

Oztekin, D., and Eratas, F. 2009. "Net Portfolio Investment and Real Interest Evaluation of the Relationship Between the Global Crisis Framework: Turkey Practice." ,Anatolia International Conference in Economics,. Eskisehir.

Pazarlioglu, M., and Gulay, E. 2007. "Net Portfolio Investment and Real Interest Relationship Between: The Case of Turkey." Dokuz Eylul University Journal of the Institute of Social Sciences, pp.208-209.

Poshakwale,S. and Thapa,C. 2007. "Impact Of Foreign Portfolio Investments On Market Comovements: Evidence From The Emerging Indian Stock Market." Emerging Market Group ESRC Seminar on International Equity Markets Comovements and Contagion, pp.1718 , London.

Pramod Kumar ,N., and Puja, P. 2015. "An Empirical Evidence of Dynamic Interaction between Institutional Fund Flows and Stock Market Returns in India." Indian Journal of Finance, Volume 9,Issue 4.

Rogoff, K. 1999. "International Institutions For Reducing Global Financial linstability." Journal of Economic Perspectives 13 , no. 4 : $21-42$

Sevil,G.; Ozer,M.;and Kulali,G. 2012. "Foreign Investors and Noise Trade in Istanbul Stock Exchange." International Journal of Business and Social Science, Vol. 3, No. 4 : 93-101

Sims, C. 1980. "Macroeconomics and Reality." Econometrica 48, no.1 : 1-48

Somuncu,M. and Karan,M.B. 2010. "The Impacts Of Internatıonal Portfolio Investments On Istanbul Stock Exchange Market." Journal of Turkish Court of Accounts, no.77: 149-167.

Stock,H.J., and Watson,M.W. 2007. "Introduction to Econometrics.”, pp.112-114 Prentice Hall.

Turgut, A. 2006. “Financial Integration and Financial Crisis in Turkey Example: 1994,2000,2001 Crisis." pp.108-110, PhD Thesis.

Vergil,H., and Karaca,C. 2010. "Impact on Economic Growth of the International Capital Flows Towards Emerging Country: Panel Data Analysis." Ege Academic Review, Volume 10, No 4:1207-1216

Williamson, J. 2002. “Financial Liberalization an Examination (Translation book)." Liberte Publisher.

Yeldan,E.,Balkan,E. and Bicer,F.G. 2002. "Patterns of Financial Capital Flows and Accumulation in the post-1990 Turkish Economy." METU International Conference. 